\title{
PROSPEK PENGEMBANGAN USAHA DODOL PEPAYA (Carica papaya L.) PADA HOME INDUSTRI "DUA SAUDARA" DESA TEBAT MONOK KECAMATAN KEPAHIANG KABUPATEN KEPAHIANG
}

\author{
BUSINESS DEVELOPMENT PROSPECT \\ OF PAPAYA (Carica papaya L.) DODOL AT "DUA SAUDARA" \\ HOME INDUSTRY TEBAT MONOK VILLAGE KEPAHIANG DISTRICT
}

\author{
Pariang Simanjuntak ${ }^{1}$, Herri Fariadi ${ }^{2}$, Rika Dwi Yuli $\mathbf{H}^{3}$ \\ 1) Program Studi Agribisnis Fakultas Pertanian UNIVED \\ 2) Program Studi Agribisnis Fakultas Pertanian UNIVED \\ ${ }^{3)}$ Program Studi Agribisnis Fakultas Pertanian UNIVED
}

\begin{abstract}
ABSTRAK
Pada dasarnya tanaman buah-buahan dapat ditingkatkan nilai tambahnya dengan mengolahnya menjadi berbagai jenis makanan. Salah satu produk olahan di Kabupaten Kepahiang yang berbahan baku pepaya (Carica papaya L.) adalah dodol pepaya. Pengembangan usaha industri pengolahan dodol dengan skala usaha kecil memiliki prospek yang cukup baik mengingat potensi pasarnya sangat mendukung. Selain itu proses pembuatan dodol buah pada dasarnya tidak terlalu sulit dan memiliki nilai ekonomis yang cukup menggiurkan. Karena itu maka timbul ide untuk mengolah pepaya agar punya nilai jual dan memperpanjang umur simpan. Adapun tujuan penelitian ini adalah untuk mengidentifikasi ketersediaan bahan penunjang, keuntungan, kelayakan, dan prospek pengembangan industri pengolahan dodol pepaya "Dua Saudara" Desa Tebat Monok Kecamatan Kepahiang. Metode analisis data yang digunakan dalam penelitian ini adalah analisis ketersediaan bahan penunjang dan analisis SWOT. Dari hasil penelitian diketahui bahwa ketersediaan bahan penunjang untuk pengolahan dodol pepaya "Dua Saudara" berupa tepung ketan, gula pasir, gula merah, dan kelapa tercukupi. Strategi pengembangan dapat dilakukan dengan strategi agresif yaitu dengan meningkatkan penjualan untuk memperbesar keuntungan dengan cara meningkatkan akses pasar yang lebih luas
\end{abstract}

Kata kunci: dodol pepaya, analisis finasial, prospek

\section{ABSTRACT}

Basically fruit plants can be increased by the value added process into different kinds of food. One of the products processed in the District Kepahiang made from raw papaya (Carica papaya L.) is a papaya dodol. The development of industrial-scale processing dodol small business has good prospects given the potential market is very supportive. Furthermore the process of making fruit dodol basically not too difficult and it has economic value is quite tempting. Hence arose the idea to cultivate papaya that has selling value and extend shelf life. The purpose of this study was to identify the development prospects papaya dodol processing home industry "Dua Saudara " at Tebat Monok Village, District Kepahiang. The data analysis method used in this research is SWOT analysis. The survey results revealed 
that the availability of support for the processing of pepaya dodol "Dua Saudara" in the form of sticky rice flour, sugar, brown sugar, and coconut sufficient.

Keywords: papaya dodol, Financial analysis, Prospects

\section{PENDAHULUAN}

Sumber daya pertanian di Indonesia merupakan salah satu keunggulan yang secara sadar telah dijadikan salah satu pilar pembangunan dalam bentuk agroindustri, baik pada orde baru, reformasi dan saat ini. Pertanian akan mampu menjadi penyelamat bila dilihat sebagai sebuah system yang terkait dengan industri dan jasa. Jika pertanian hanya berhenti sebagai aktivitas budidaya (on farm agribusiness) nilai tambahnya kecil. Nilai tambah pertanian dapat ditingkatkan melalui kegiatan hilir (off farm agribusiness), berupa agroindustri dan jasa berbasis pertanian (Mangunwidjaja dan Illah, 2005).

Salah satu jenis tanaman buah-buahan yang digemari oleh masyarakat adalah papaya (Carica papaya L.). Komoditi hortikultura ini memiliki nilai ekonomis yang tinggi dan merupakan salah satu komoditas buah yang kaya akan fungsi dan manfaat. Pepaya masak memiliki kandungan gizi yang cukup tinggi yaitu gula buah $10 \%$, zat asam $0,1 \%$, lemak 0,1 $\%$, abu $0,6 \%$, serat $0,7 \%$ dan air $90 \%$. Didalamnya juga terdapat kandungan vitamin A dan vitamin C. Buah pepaya mengandung enzim papain yang sangat aktif dan memiliki kemampuan mempercepat proses pencernaan protein, karbohidrat dan lemak (Anonim, 2007). Pengembangan usaha industri dodol dengan skala usaha kecil menengah memiliki prospek yang cukup baik, mengingat potensi pasarnya sangat mendukung. Selain itu, proses pembuatan dodol buah pada dasarnya tidak terlalu sulit dan memiliki nilai ekonomis yang cukup menggiurkan (Satuhu dan Sunarmani, 2008).

Kabupaten Kepahiang sudah sejak lama dikenal sebagai penghasil buah pepaya di Bengkulu dengan tingkat produksi 1.917,9 ton/tahun (Dinas Pertanian Kabupaten Kepahiang, 2011). Di Kabupaten Kepahiang sudah ada industri kecil pengolahan buah pepaya yang menjadi produk turunan seperti dodol pepaya. Pengolahan buah pepaya ini bertujuan memperpanjang umur simpan dan mempunyai nilai jual. Keunggulan dodol pepaya merupakan makanan tradisional yang cukup populer dibeberapa daerah Indonesia dan memiliki rasa yang khas dan enak (Satuhu dan Sunarmani, 2008). 
Strategi pengembangan industri pengolahan dodol papaya di masa yang akan datang dapat dilakukan dengan strategi Agresif yaitu dengan meningkatkan pertumbuhan penjualan untuk memperbesar keuntungan. Berdasarkan latarbelakang diatas maka tujuan dari penelitian ini adalah untuk mengidentifikasi ketersediaan bahan penunjang, keuntungan, kelayakan, dan prospek pengembangan industri pengolahan dodol pepaya "Dua Saudara" Desa Tebat Monok Kecamatan Kepahiang.

\section{METODE PENELITIAN}

Penelitian ini dilaksanakan pada bulan bulan Juni 2012 pada Industri Dodol "Dua Saudara" yang berlokasi di Desa Tebat Monok, Kecamatan Kepahiang, Kabupaten Kepahiang, Provinsi Bengkulu. Lokasi penelitian terpilih yaitu Industri Dodol "Dua Saudara" di Desa Tebat Monok, Kecamatan Kepahiang, Kabupaten Kepahiang karena daerah tersebut merupakan salah satu sentra produksi pepaya. Metode pengambilan sampel dilakukan dengan cara purposive yaitu teknik penentuan sampel dengan pertimbangan tertentu (Sumarsono, 2004).

Data yang dikumpulkan diperoleh dari data primer diperoleh secara langsung melalui wawancara kepada responden dengan menggunakan daftar pertanyaan (kuisioner) yang dibuat terlebih dahulu. Sedangkan data sekunder merupakan data pelengkap yang diperoleh dari instansi atau lembaga terkait seperti Dinas Pertanian Kabupaten Kepahiang, Dinas Koperasi, UKM, Perindustrian dan Perdagangan Kabupaten Kepahiang, serta literatur yang berhubungan dengan penelitian ini.

\section{Analisis Ketersediaan Bahan Penunjang}

Digunakan untuk identifikasi masalah (1) ketersediaan bahan penunjang pada industri pengolahan dodol pepaya "Dua Saudara" di Desa Tebat Monok Kecamatan Kepahiang dianalisis secara deskriptif, dengan kriteria :

Jika ketersediaan $>$ konsumsi maka ketersediaan tercukupi (Hipotesis diterima) Jika ketersediaan $<$ konsumsi maka ketersediaan tidak tercukupi (Hipotesis ditolak)

\section{Analisis SWOT}

Menurut Situmorang dan Dilham (2007) dalam membuat analisis SWOT dapat dilakukan langkah-langkah sebagai berikut

1. Persiapan : Menyamakan Pemahaman (Persepsi)

a. Perlunya identifikasi terhadap peluang dan ancaman yang dihadapi serta kekuatan dan kelemahan yang 
dimiliki organisasi melalui penelaahan terhadap lingkungan usaha dan potensi sumber daya organisasi dalam menetapkan sasaran dan merumuskan strategi organisasi yang realistis dalam mewujudkan visi dan misinya.

b. Mengumpulkan jenis dan kualitas data dan informasi yang internal dan eksternal yang diperlukan

c. Menyamakan langkah-langkah (prosedur) dalam melakukan analisis eksternal dan internal.

2. Mengidentifikasi Faktor Internal dan Faktor Eksternal

a. Internal Faktor (Identifikasi Kekuatan dan Kelemahan)

b. Eksternal Faktor (Identifikasi Peluang dan Ancaman)

c. Melakukan Pembobotan

\section{HASIL DAN PEMBAHASAN}

Ketersediaan Bahan Penunjang

Berdasarkan tabel 1 di bawah ini dapat disimpulkan bahwa ketersediaan tepung ketan, kelapa, gula pasir, dan gula merah di Kabupaten Kepahiang mencukupi kebutuhan tepung ketan, kelapa, gula pasir, dan gula merah untuk industri pengolahan dodol pepaya “ Dua Saudara”. Dengan demikian hipotesis 1 yang menyatakan ketersediaan bahan penunjang untuk industri pengolahan dodol pepaya "Dua Saudara" tercukupi diterima. Dengan tersedianya bahan penunjang untuk industri pengolahan dodol pepaya "Dua Saudara" maka dodol pepaya akan dapat diproduksi secara berkelanjutan untuk memenuhi permintaan konsumen.

Tabel 1. Ketersediaan dan Konsumsi Tepung Ketan, Kelapa, Gula Pasir, Gula Merah di Kabupaten Kepahiang dan Kebutuhan Industri Pengolahan Dodol Pepaya "Dua Saudara" Tahun 2011

\begin{tabular}{|c|c|c|c|c|c|}
\hline No & $\begin{array}{c}\text { Bahan } \\
\text { Penunjang }\end{array}$ & $\begin{array}{l}\text { Ketersediaan } \\
\text { (Kg/ Thn) }\end{array}$ & $\begin{array}{l}\text { Konsumsi } \\
\text { (Kg/Thn) }\end{array}$ & $\begin{array}{c}\text { Kebutuhan "Dua } \\
\text { Saudara" } \\
\text { (Kg/Thn) }\end{array}$ & $\begin{array}{c}\text { Persentase } \\
\quad(\%)\end{array}$ \\
\hline 1 & $\begin{array}{l}\text { Tepung } \\
\text { Ketan }\end{array}$ & 30.000 & 28.800 & 1.080 & 3,60 \\
\hline 2 & Kelapa & 360.000 (butir) & 274.560 & 1.080 & 0,90 \\
\hline 3 & Gula Pasir & 299.000 & 271.872 & 1.080 & 0,36 \\
\hline 4 & Gula Merah & 120.000 & 80.064 & 720 & 0,60 \\
\hline
\end{tabular}

Sumber : Dinas Perindustrian dan Perdagangan Kabupaten Kepahiang, 2011

Analisis SWOT

Strategi-strategi pengembangan usaha industri kecil pengolahan dodol papaya "Dua Saudara" dapat dilakukan dengan 
beberapa alternatif. Penentuan alternatif strategi yang sesuai bagi pengembangan industri pengolahan dodol pepaya "Dua Saudara" adalah dengan cara membuat matriks SWOT berdasarkan faktor-faktor strategi baik internal (kekuatan dan kelemahan) maupun eksternal (peluang dan ancaman). Berdasarkan matriks posisi analisis SWOT maka disusun empat strategi utama yaitu : SO, WO, ST, dan WT. Alternatif strategi prospek pengembangan industri dodol pepaya "Dua Saudara" pada tabel berikut :

Tabel 2. Penentuan Strategi dengan Matriks SWOT

\begin{tabular}{|c|c|c|}
\hline Inter & Kekuatan (S) & Kelemahan (W) \\
\hline Eksternal & $\begin{array}{l}\text { 1. Lokasi di daerah bahan } \\
\text { baku yaitu di desa Tebat } \\
\text { Monok } \\
\text { 2. Lokasi strategis } \\
\text { 3. Sudah terdaftar di Depkes } \\
\text { 4. Tenaga kerja mudah didapat } \\
\text { dengan upah yang dapat } \\
\text { disanggupi oleh pemilik } \\
\text { usaha }\end{array}$ & $\begin{array}{l}\text { 1. Modal terbatas } \\
\text { 2. Kemasan masih sederhana } \\
\text { 3. Kurangnya kemampuan } \\
\text { promosi dan distribusi }\end{array}$ \\
\hline Peluang (O) & Strategi SO & Strategi WO \\
\hline $\begin{array}{l}\text { 1.Dukungan kebijakan } \\
\text { pemda } \\
\text { 2.Budaya masyarakat } \\
\text { membeli oleh-oleh } \\
\text { 3.Belum ada usaha yang } \\
\text { sama di Kepahiang tahun } \\
2012\end{array}$ & $\begin{array}{l}\text { 1. Mendorong masyarakat } \\
\text { untuk meningkatkan } \\
\text { produksi bahan baku } \\
\text { 2. Meningkatkan kualitas } \\
\text { produk agar mampu } \\
\text { menjaring lebih banyak } \\
\text { konsumen }\end{array}$ & $\begin{array}{l}\text { 1. Perhatian pemerintah } \\
\text { dalam bentuk pemberian } \\
\text { bantuan modal dan } \\
\text { peralatan } \\
\text { 2. Meningkatkan promosi } \\
\text { agar mampu menjangkau } \\
\text { pasar yang lebih luas }\end{array}$ \\
\hline Ancaman (T) & Strategi ST & Strategi WT \\
\hline $\begin{array}{l}\text { 1. Munculnya usaha yang } \\
\text { sama memproduksi dodol } \\
\text { pepaya } \\
\text { 2.Kenaikan tarif listrik dan } \\
\text { BBM tahun 2011 } \\
\text { 3.Perekonomian yang tidak } \\
\text { stabil }\end{array}$ & $\begin{array}{l}\text { 1. Menjamin kontinuitas } \\
\text { produksi } \\
\text { 2. Memasuki dan menguasai } \\
\text { daerah pemasaran di } \\
\text { seluruh Provinsi Bengkulu }\end{array}$ & $\begin{array}{l}\text { 1. Memanfaatkan modal } \\
\text { yang terbatas dan inisiatif } \\
\text { kredit untuk menambah } \\
\text { modal } \\
\text { 2. Menciptakan kemasan } \\
\text { yang lebih menarik dan } \\
\text { lebih ekonomis agar dapat } \\
\text { terjangkau oleh konsumen } \\
\text { misalnya dalam bentuk } \\
\text { kotak. }\end{array}$ \\
\hline
\end{tabular}

Sumber : Data Primer setelah diolah, 2012 
pengolahan dodol pepaya"Dua Saudara" dengan menggunakan seluruh kekuatan dan peluang yang ada, yaitu :

1. Mendorong masyarakat untuk meningkatkan produksi bahan baku

Kebijakan Pemda dalam mendorong masyarakat untuk meningkatkan produksi bahan baku bertujuan agar ketersediaan bahan baku selalu tersedia sehingga produksi dodol pepaya dapat terus berjalan. Dengan selalu tersedianya bahan baku maka harganya akan selalu stabil sehingga biaya produksi lebih efisien dan keuntungan yang diperoleh semakin meningkat.

2. Meningkatkan kualitas produk agar mampu menjaring lebih banyak konsumen

Tetap menjaga kualitas produk dengan melakukan kontrol kualitas dari awal hingga akhir produksi sehingga konsumen dodol pepaya "Dua Saudara" meningkat.

\section{Strategi WO}

Strategi pengembangan industri pengolahan dodol papaya "Dua Saudara" dengan meminimalkan seluruh kelemahan untuk memanfaatkan peluang yang ada, yaitu :

1. Perhatian pemerintah dalam bentuk pemberian bantuan modal dan peralatan

Dengan adanya bantuan modal dari Pemda maka akan mempercepat perkembangan industri dodol pepaya "Dua Saudara" karena dapat menambah jumlah produksi yang memungkinkan meningkatnya keuntungan.

2. Meningkatkan promosi agar mampu menjangkau pasar yang lebih luas

Bertujuan agar seluruh produk yang dihasilkan dapat dipasarkan ke daerah yang lebih luas bukan hanya di daerah produksi saja.

\section{Strategi ST}

Strategi pengembangan industri pengolahan dodol pepaya"Dua Saudara" dengan menggunakan seluruh kekuatan untuk mengatasi ancaman yang ada, yaitu :

1. Menjamin kontinuitas produksi

Hal ini harus dilakukan mengingat belum adanya pesaing yang menghasilkan produk yang serupa.

2. Memasuki dan menguasai daerah pemasaran

Sebelum muncul pesaing yang serupa maka industri pengolahan dodol pepaya "Dua Saudara" harus dapat memasuki dan menguasai pasar dengan cara mengikuti pameran- pameran industri dan menjalin kerjasama dengan berbagai pihak sehingga daerah pemasaran tidak akan terebut oleh pesaing yang kemungkinan akan muncul.

\section{Strategi WT}

Strategi pengembangan industri pengolahan dodol pepaya "Dua Saudara" 
dengan meminimalkan kelemahan dan menghindari ancaman yang ada, yaitu :

1. Memanfaatkan modal yang terbatas seefisien mungkin agar usaha mampu berkembang.

Dengan memiliki modal yang terbatas maka perlu diperhatikan efisiensi produksi sesuai dengan permintaan pasar dan berusaha menambah modal melalui pinjaman agar usaha lebih cepat berkembang.

2. Menciptakan kemasan yang lebih menarik dan lebih ekonomis agar dapat terjangkau oleh konsumen .

Untuk mencapai penjualan yang semakin meningkat maka melalui kemasan yang lebih menarik merupakan salah satu cara untuk mempromosikan produk yang dihasilkan dengan memperhatikan jangkauan para konsumen.

Dari analisis SWOT dapat dilihat posisi industri kecil pengolahan dodol pepaya “ Dua Saudara" berada pada kondisi yang sangat menguntungkan karena mempunyai kekuatan dan peluang yang dapat dimanfaatkan sehingga prospek pengembangannya akan sangat menguntungkan untuk dijalankan.

\section{SIMPULAN}

Ketersediaan bahan penunjang industri pengolahan dodol pepaya "Dua Saudara" berupa tepung ketan, gula pasir, gula merah, dan kelapa tercukupi. Strategi pengembangan industri pengolahan dodol pepaya "Dua Saudara" dapat dilakukan dengan strategi agresif yaitu dengan meningkatkan penjualan untuk memperbesar keuntungan dengan cara meningkatkan akses pasar yang lebih luas.

\section{SARAN}

Industri pengolahan dodol pepaya" Dua Saudara" perlu memperbaiki proporsional pekerja, menambah peralatan yang lebih modern, dan disarankan untuk memanfaatkan sebesar-besarnya peluang dan kekuatan dan menekan serendah mungkin ancaman dan kelemahan. Promosi produk dodol pepaya "Dua Saudara" perlu ditingkatkan untuk mencapai pemasaran yang lebih luas dengan cara mengikuti pameran-pameran industri, membuat kemasan yang lebih menarik dan mencantumkan kandungan gizi dari dodol pepaya serta menjalin kerjasama dengan berbagai pihak. Pemerintah Daerah Kabupaten Kepahiang harus tetap memberi dukungan bagi industri pengolahan dodol pepaya "Dua Saudara" untuk mengatasi keterbatasan modal dengan cara memberikan bantuan modal dan peralatan, mengadakan pelatihan-pelatihan produksi untuk 
meningkatkan kualitas produk.

\section{DAFTAR PUSTAKA}

Anonim . 2007. Agribisnis Usaha Tani Pepaya dan Papain. Dikutip dari http://www.cianjur.go.id

Dinas Pertanian Tanaman Pangan Kabupaten Kepahiang Provinsi Bengkulu. 2011. Laporan Tanaman Buah-buahan dan Sayuran Tahunan Kabupaten Kepahiang.

Dinas Koperasi, UKM, Perindustrian dan Perdagangan Kabupaten Kepahiang Provinsi Bengkulu. 2011. Data Ketersediaan dan Konsumsi Bahan Pangan di Kabupaten Kepahiang.

Gray, C., P. Simanjuntak, L.K. Sabar dan P.F.L.Maspeitella. 2002. Pengantar Evaluasi Proyek. PT. Gramedia, Jakarta.

Hasibuan, Malayu S.P. 1996. Manajemen Dasar ; Pengertian dan Masalah. Toko Gunung Agung. Jakarta.

Ibrahim, Y.H.M. 2009. Studi Kelayakan Bisnis. Rineka Cipta, Jakarta.

Laila Nurhasanah Siregar, 2009. Analisis Finansial Industri Pengolahan Dodol Salak dan Prospek Pengembangannya (Studi Kasus di Desa Parsalakan

Kabupaten Tapanuli Selatan). Skripsi FP USU Medan.

Mangunwijaya, Djumali dan Illah Sailah. 2005. Pengantar Teknologi Pertanian. Penebar Swadaya, Jakarta.
Muktiani. 2011. Bertanam Varietas Unggul Pepaya California. Pustaka Baru Press, Yogyakarta.

Muzhar, M. 2002 Pengembangan Agroindustri dan Berbagai Permasalahannya. Berita Ilmu Pengetahuan dan Teknologi. Tahun ke- 38 No. 1.

Phillip K, 2000. Marketing Management, Prentice Hall, New Jersey.

Rahardja, P. dan Mandala Manurung. 2000. Teori Ekonomi Mikro. Fakutas Ekonomi UI, Jakarta.

Rangkuti, F. 2011. SWOT Ballanced Scorecard "Teknik Menyusun Strategi Korporat yang Efektif Plus Cara Mengelola Kinerja dan Resiko”. PT. Gramedia Pustaka Utama, Jakarta.

Samuelson. 2001. Ilmu Mikro Ekonomi. Media Global Edukasi, Jakarta.

Satuhu, Suyati dan Sunarmani. 2008. Membuat Aneka Dodol Buah. Penebar Swadaya, Jakarta.

Situmorang, S dan Dilham, A. 2007. Studi Kelayakan Bisnis. USU Press, Medan.

Soewono, L. 2005. Pemanfaatan Teknologi Pascapanen Untuk Pengembangan Industri Berbasis Pertanian. Diakses dari http://id.wilkipedia.org/wiki/Agroin dustri

Sukmawati. 2009. Upaya Wujudkan Kesejahteraan dan Kemandirian Petani. Diakses dari http://kasper 55185.wordpress.com/category/unc ategorized/ 